\title{
EVOLUTION OF PROJECT BASED ORGANIZATION: A CASE STUDY
}

\begin{abstract}
Little research has been conducted on how project based organizations navigate internal and external pressures to develop and improve project competences over time. Using a cases study approach, this paper examines the development and implementation of project based organization over a period of 30 years. Overall, the evolution of project management competencies in the organization broadly followed the prevailing approaches in improving organizational management practices uncovered in review of literature. The organization's capability to adopt and implement project management frameworks improved over time as senior managers became more masterful at matching improvement actions into the organizational context. This research also presents how a systematic approach of project management maturity models for identifying and implementing project management practices and processes can increase the effectiveness and comprehensiveness of overall management practices. The study concludes with a series of recommendations in further improving project management practices and processes in project based organizations.
\end{abstract}

Keywords: Evolution, Project Based Organization, Project Management Maturity Models, Case Study 


\section{Introduction}

The purpose of this paper is to examine the longitudinal evolution of project management competence in a project based organization. Organizations engage in a range of interactions with their environments, ranging from arm's length market transactions to face-to-face negotiations within 'relational frameworks'(Scott, 1995). Over time, organizations may exhibit evolutionary responses in which structures and practices are adapted to changing conditions in the external environment (Marsh \& Stock, 2006). The development and proliferation of mass production techniques resulted in the emergence of large scale manufacturing organizations designed around long term and repetitive processes (Chandler, 1969; Ford \& Randolph, 1992). As the environment became more competitive, firms began to initiate increasing numbers of projects (Packendorff, 1995) and these projects began influencing firms' structure as they were distinct social systems that spanned multiple departments, customers and suppliers (Martinsuo, Hensman, Artto, Kujala, \& Jaafari, 2006; Turner \& Muller, 2002). Researchers began suggesting that some firms could be classified as project based organization (Gareis, 1989).

The projectification process involves the adaptation of the methods and means of the organization as well as the implementation of project activities. Per Packendorff and Lindgren Packendorff and Lindgren (2014, p. 7), the project form is the preferred methodology because they are "perceived as a controllable way of avoiding all the classic problems of bureaucracy." In this perspective, projects, not departments, become the unit of control and the role of management is to manage the relationships between projects and their environment, both internal (within the company) and external (outside the company). While hierarchies may still exist (Massini \& Pettigrew, 2003), managing these project networks required two processes: described as integration and differentiation (Gareis, 1991). Integration is the responsibility of company 
administration and involves the incorporation of project inputs and outputs into a company-wide framework. Differentiation is the responsibility of project teams and involves the creation of new projects to solve problems or access opportunities.

In project based organizations, project management is a strategic competency and improving performance in this domain is of great importance (Erdogan, Anumba, Bouchlaghem, \& Nielsen; Green, 2005). However, due to the continually changing nature of project-based organizations, it is a challenge for management of these firms to improve performance (Koskinen, 2012). According to Packendorff and Lindgren (2014), research on project activities has traditionally been focused on single projects as the unit of analysis. Therefore, they argue an enhanced understanding of the processes of projectification would be beneficial to project research. Based on earlier empirical research on the sustenance of project work form and the consequences, they introduce a distinction between narrow and broad conceptualizations of projectification. While work has examined how projects can transform pre existing operational structures, little work has examined the development of project based organizations over an extended period of time. This paper seeks to extend existing research on project based organizations by examining the longitudinal path of development of a construction organization in the Middle East.

\section{Research Questions and Methodology}

A longitudinal case study approach has been used to explore the following questions:

- What were the improvement actions undertaken by the project based organization over time?

- What was the effect on competencies and the emergent path of development of the project based organization? 
- What improvement approaches are used for planning and managing changes?

For this study, a project-based organization to highlight organizational project management features that are widely adopted by organizations in the construction sector has been selected. The longitudinal approach has been conducted because over time, a trajectory of development may emerge as firms assess and improve their practices over time. Understanding this process will be of value to both researchers and project managers (Mullaly, 2006). Most extant research on maturity models has taken a cross sectional approach, examining the degree to which project management has been adopted in the organization. However, this perspective is limited as organizations are dynamic entities in which the context and practices change over time. In these conditions, cross sectional approaches may not clearly identify interconnections between improvement efforts and observed outcomes. By contrast, a longitudinal approach for studying organizational development can provide a greater understanding of enablers and barriers to improving project practices in firms by uncovering the temporal order of events and the underlying patterns, including possible associations between events, actions and outcomes.

Maturity models have been proposed as tools for improving project performance. They also imply a longitudinal path of development in which organizations progress over time from lower to higher levels of project management competence. Therefore the paper starts with a critical review of the background, common concepts and limitation of maturity approaches to development of project based organizations. These concepts are then applied in a longitudinal study of a project-based construction organization has been conducted. This research makes both theoretical and empirical contributions to the body of knowledge in project management. Theoretically, it provides new insights into the effect of maturity models on organizational development. Overall, a review of the project based organization's developmental steps shows a 
trajectory of development that only partially aligns to the perspective implied by maturity models. Further, within that overall path, both evolution (adoption of prevailing frameworks) and coevolution (adaptation of practices to context) between project practices and the company context occurred over time in the organization. This study also found that increasing the effectiveness and comprehensiveness of improvement efforts over time are the main advantages of maturity models. By comprehensiveness we refer to the capability of the project management maturity framework for covering different aspects of the organization's work. By effectiveness of the approach we mean the capability of its mechanism for identifying, prioritizing and leading required improvement actions. Empirically, the research examines project management maturity in an emerging market, a context, while important has received little attention in the literature to date. Finally, the findings reveal a number of organizational context based drivers and barriers for improving project practice.

\section{Literature Review}

Maturity models are considered to be strategic tools used by senior managers to identify improvement areas and to prioritize improvement actions (Kerzner, 2001). These models originate in the earlier successful application of quality management techniques in manufacturing processes. Specifically, the idea of maturity originated in the process improvement domain here it is believed that processes can operate predictably as controllable systems. Process capability models apply this notion and define the process capability as "the quantifiable range of expected results that can be achieved by following a process" (Ibrahim et al., 2001). Accordingly, process maturity levels are defined using the concept that the expected outcome of a process is affected by the extent to which an organization deploys specific practices 
in its processes. For instance, the outcome of a statistically controlled process is different from those of uncontrolled processes (Baumert \& McWhinney, 1992). The same concept is used by different maturity models to define specific practices associated with each maturity level.

Models have developed over time to go beyond process capability only (Bate, 1995) to incorporate capability and competence of personnel involved in these processes (Hakes, 2007). Some maturity and excellence models have been extended further to specifically address change management requirements in project-driven settings (Project Management Institute, 2003) Organizational project management processes are the focus of such models. Diagnosing and analyzing the organization, designing interventions, and leading and managing improvement actions are common steps in all change approaches (Cummings \& Worley, 2009).

Based on the findings of the literature review, Table 1 summarized different steps in evolution of maturity models and their widespread use (Bate, 1995; Cleland \& Ireland, 2006; Curtis, Hefley, Miller, \& Carnegie-Mellon Univ Pittsburgh Pa Software Engineering, 2009; Hakes, 2007; Ibrahim et al., 2001; International Project Management Association, 2002; Kerzner, 2001; Y. H. Kwak \& Ibbs, 1997; Y. H. Kwak \& Ibbs, 2002; Paulk \& Software Engineering Institute, 1993; Project Management Institute, 2003; Software Engineering Institute, 2007).

\section{TABLE 1. Main Steps in the Evolution of Maturity Models}

Table 1 shows that a wide array of maturity models are available, each of which covers a specific dimension of organization's work, including operational and strategic processes, employees' capability, and elements of the management system. Tracking the history of 
improvement approaches and their primary area of focus reveals the following underlying themes can be categorized as follows.

\subsection{Process Control Perspective}

Preliminary approaches to maturity management were drawn from the quality management domain (Bate, 1995). The focus at that time was the identification, documentation, control and optimization of processes. While this approach attempted to improve various components of business, it gave equal importance to all of these components. Processes were assessed independently and the intended outcome was reliable and efficient performance of operations.

\subsection{System Perspective}

As software systems increased in complexity, the process control approach faced limits to improving outputs. To increase the effectiveness of improvement efforts, the Software Engineering Institute (SEI) expanded the view of maturity beyond individual processes to entire systems (Cleland \& Ireland, 2006). This facilitated an approach to software development that recognized the interdependent nature of processes. Later efforts of the SEI expanded the application of the maturity framework to processes and people involved in system and software development and maintenance (Bate, 1995). These separate models were then merged into one integrated model, the Capability Maturity Model Integration (Bate \& Shrum, 1998) commonly known is CMMI, which presented a path of development inspired by early maturity approaches of Nolan (1973). These models follow a longitudinal life cycle approach (Van de Ven \& Poole, 1993) in which development has a distinct start point (low competence) and end point (high 
competence) along with an underlying mechanism that drives progress or improvement (Maier, Moultrie, \& Clarkson, 2012). In these maturity models, firms begin at Level 1 and the mechanism of progress is improved practices, evidenced by improving scores on maturity model metrics based on one or more bodies of knowledge. Firms then reach the "end state" of industry leading/continuous improvement, in which processes are constantly refined.

\subsection{Organizational Perspective}

To address the multidisciplinary nature of improvement efforts and provide a means for considering the organization-wide impact of change, the Federal Aviation Administration (FAA) applied two main concepts described as "integrated process improvement" and "improving process integration" to the SEI's capability maturity models (Cleland \& Ireland, 2006). From this point forward, the application of maturity concepts has been extended beyond the software engineering domain, and different authors and institutions have tried to develop their own models for project management processes and even for specific management topics such as risk management, supply chain management, earned value management, people competencies, and the like (Campos \& Trees, 2008; Construction Industry Institute, 2006, 2009)

In contrast to CMMI, which identified best practices for all processes, some of these models focused on identifiing the characteristics of processes and suggested patterns of adoption. (Yazici, 2009). These models also suggest a longitudinal process within organizations as they indicate that organizations may follow a potential performance approach to competence development. This mode of development was suggested by Crosby (1979) which, like the life cycle approach, also proposes distinct, progressive states of development. However, unlike life cycle models, each stage is considered a destination in itself. Firms may therefore choose not to 
progress beyond a given level if they deem their capabilities sufficient to internal and external demands. This approach can be considered a teleological or goal directed approach (Van de Ven \& Poole, 1993) to competence development, in which industry best practices are ignored in preference to company objectives.

Subsequent to prevalent application of these maturity models, in 1999, Project Management Institute (PMI) launched a program for developing a model addressing the attributes of project-driven organizations. After reviewing 27 of the then available maturity models, PMI published Organizational project management maturity model (OPM3) in 2003 (PMI, 2003). As mentioned with initiatives behind developing an integrated capability maturity model (CMMI) by SEI, PMI also developed OPM3 to address the organization-wide impact of change in project-based organizations (Zqikael, Levin, \& Rad, 2008).

\section{Common Concepts among Maturity Models}

Despite the diversity of the published models, maturity models share key features. The review shows that the mechanism of maturity models is based on three main elements.

\subsection{Appraisal}

A self-assessment tool is incorporated in the model that is used to determine maturity of the organization. The output of this process is an evaluation of the organizations project management capabilities and current strengths/weaknesses in the terms of the project management model (Backlund, Chronéer, \& Sundqvist, 2014). Self-assessment is one of the most important characteristics of maturity models and distinguishes them from other improvement approaches listed in Table 1, such as statistical process control and total quality management (TQM). 


\subsection{Body of knowledge}

In all models, capabilities and competencies associated with different maturity levels, along with capability-related performance indicators, are structured to support the function of the model. These generally rely on one or more bodies of knowledge drawn from a particular perspective on project management such as PRojects IN Controlled Environments (PRINCE2), used by the UK government, and models developed by International Project Management Association (IPMA) or PMI (Bellini \& Lo Storto, 2006).

\subsection{Improvement}

Based on the assessment results and by using the capabilities listed in the knowledge element, the improvement function of the model provides a prioritized list of actions and identifies a longitudinal path of future development. This aspect moves maturity models beyond cross sectional, short term interventions to longer term organizational inititiaves. Implementation of these actions generally requires the adjustment of resources over time which may include organizational or staff development. Additionally, the body of the knowledge of the models has similar structures. For each maturity level, a series of best practices is defined for which prerequisite capabilities are listed. Improvement is in fact made by attaining those capabilities, and it can be demonstrated by verifying a specific outcome that is expressed in terms of key performance indicators. Table 2 summarizes these shared characteristics.

\section{INSERT}

\section{TABLE 2. Common Features Among Maturity Models}




\subsection{Critical Evaluation of Maturity Models}

Project management Maturity models make several claims whose underlying assumptions can be debated. The first is that project management competencies can be accurately measured which assumes that they can be objectively quantified. This assumption originates in the capability view of quality management where processes can be controlled within predetermined parameters. While this may be possible in some domains of organizational activity, such as manufacturing operations where a discrete area of activity or task can be defined and measured(Shah \& Ward, 2007). Project management processes rely heavily on interactions between individuals which may be difficult to quantify (Medina $\&$ Medina, 2014). As a result, maturity measures seeking to provide an evaluation of these processes may be subjective (E. S. Andersen \& Jessen, 2003) and vary by the context in which they are applied, the perspective of the evaluator and the type of framework being applied.

The second claim is that there is a universal agreement on practices. Research in the area of organizational ecology indicates that practices adopted by a given organization are contextual as they need to fit internal and external selection criteria, a proposition supported by project management researchers (Shenhar, 2001), By proposing measures based on predefined characteristics, maturity models also assume that there is a given set of project capabilities that are important to all organizations without regard to intent, industry or geography. This is at odds with extant research in project management as(Cooke-Davies, Crawford, \& Lechler, 2009)suggest that project management capabilities need to be aligned with overall organizational strategic intent in order to generate value. This implies that project capabilities developed by organizations may vary even within a given industry as organizational approach will determine the capabilities developed, not the maturity models adopted (Mullaly \& Thomas, 2009). Further, 
comparative research (Graham, 1999) demonstrates differing project approaches by industry based on systems for allocating value and managing delivery. Similar findings have been found the influence of country environment on project practices (Ling, Ong, Ke, Wang, \& Zou, 2014).

The third claim of maturity models is that there is a predetermined path of development. The core concept of these maturity models is that competence development in organizations takes a lifecycle approach or a teleological (potential performance) approach (Wendler, 2012). However, alternate patterns of development beyond life cycle and teleological can occur in organizations. Firms can adopt an evolutionary approach, for example, where they engage in a continuous process of variation-selection-retention (Miller, 1982). That is, firms can experiment with differing project practices, observe their performance and the ones most appropriate to the organizational environment are selected and retained for future use. Under these conditions, project competency development would be continuous and would not be classifiable into distinct stages. For example, research on software firms (Seppänen, 2002) have identified that relational strategies evolve over time based on supplier and firm development, not via a priori maturity model guidelines. Further, since strategy can drive PM, this suggests that. Beyond single patterns of development an emerging stream of research has theorized that in the face of complexity project management can follow multiple paths of development simultaneously or abandon them entirely to improvise solutions based on situations (Klein, Biesenthal, \& Dehlin, 2015).

Finally, maturity models claims that improvement in specified domains results in improved organizational performance. This claim rests on the assumption that there is a direct relationship between project management competencies and organizational performance. (Crawford, Hobbs, \& Turner, 2006). However, academic research on the contribution of project 
management to the financial outcomes of organizations have identified both significant (Lappe \& Spang, 2014) and not significant (Dai \& Wells, 2004) relationships. Outside of financial measures, research on project success has looked at non-financial measures in the form of factors, conditions that enable positive results (Jugdev \& Müller, 2005) and criteria, measures used to evaluate project outcomes (Cooke-Davies, 2002). However direct linkages between factors and criteria have not yet been empirically validated (Young \& Grant, 2015). Overall, for researchers the challenges to maturity models assumptions indicates that a holistic understanding of the organizational context is required to understand the rationale, drivers and outcomes of implementation.

\section{Data Collection}

This research examines how practices have evolved in a Project Based Organization located in an emerging market. Research into evolving organizations is highly complex as it requires the collection of data about how events, actions and decisions evolve over time (Langley, 1999). Understanding the context in which this evolution takes place is a key component of this type of research. Data collection was conducted using a single case study as it enables the in depth exploration of a given setting (Voss, Tsikriktsis, \& Frohlich, 2002) and provided an avenue for examining complex, evolving phenomena. The authors gathered information from the following sources.

- Open-ended questionnaires sent to senior and middle managers whose area of work has been subjected to improvement projects in recent years. Seven out of fifteen questionnaires returned by three senior managers and four middle managers. Senior managers have been employed by the organization for more than 15 years. 
- Follow-up Interviews with the organization's senior managers in charge of improvement projects. Two individuals separately participated in a one-hour semi-constructed interview and one individual participated in three one-hour semi-constructed interviews. Middle managers have been employed by the organization for more than seven years.

- Open-ended questionnaires sent to the members of teams involved in implementing one of the major improvement projects currently underway. Four out of five questionnaires returned. Team members were involved in the project between six to eighteen months.

- Review and assessment of relevant archival documents: In 2003, the Company developed a detailed procedure for evaluating its management system and defined relevant indicators, such as employee satisfaction, customer satisfaction and loyalty, number and value of contracts per year and profit margin for quantifying and documenting various aspects of its performance.

For analysis, building theoretical understanding or "sensemaking" (Langley, 1999), this research also employed multiple strategies, each with distinct strengths in the ability to discern patterns, underlying mechanisms, meanings and prediction. Narratives served as an initial device to summarize data and visual mapping was utilized to support analysis by displaying sequences of events (Langley, 1999).

\section{Case Study}

\subsection{Organization Background}

The XYZ (name has changed) Company was founded in the early 1980s in a developing country in Asia and provides engineering and management consulting services in the 
construction sector. With respect to different criteria, including age, the number of employees, the size and number of projects done by this company, and most importantly, adopting new management theories and paradigms, this firm is one of the leading companies in the country. Some of the most important characteristics of the company's workflow include:

- Based upon the project type, when a new project starts, it is assigned to the relevant technical division.

- Technical divisions work as parts of a larger functional department.

- Each functional department has a supervision division in charge of providing supervisory services during the construction phase.

- Each functional department has its own program management division that provides project management services to all projects undertaken by the host department.

- Relevant projects are grouped as different programs and managed in a coordinated way in each department.

Table 3 summarizes different steps that the organization under study has pursued to improve its capabilities and specify outcomes of each step.

\section{INSERT}

TABLE 3. Major Improvement Actions and Outcomes of XYZ Company

\subsection{Improvement Steps and Application of Improvement Approaches}

In interviews conducted as a part of this study, the participants mentioned that the major driving force for changes listed in Table 3 was gaining more capability for achieving further benefits from projects and improving the overall accomplishments of the company. In summary, these changes have been categorized into the following major areas: 
- Quality program and the organization's mission and vision

- Characteristics of projects in terms of location, type, size, and delivery method

- Organizational and project-level work flow, and

- Organizational structure

Analyzing the information provided in Table 3 shows a clear trajectory of development in XYZ Company.

Stage 1: During the early years after establishment of the company, the role of projects in the firm's business received particular attention, and changes were directed toward weighting project-based characteristics of the organization. In accordance with these organizational characteristics including structure, roles, authorities, and responsibilities were adapted to the new project focus.

Stage 2: In the second phase, company leaders decided to establish an ordered and structured process for pursuing objectives. They launched a standardization program with emphasis on quality management processes and adopted concepts from the ISO standards framework.

After the standardization step, the managers used the EFQM excellence model to further improve the quality management system. As a part of the Project Excellence Program, the company decided to use PMI's PMBOK framework for standardizing project management processes. In the second stage, in line with changes in the organizational structure, the firm's senior managers added competencies of the project personnel to the scope of improvement actions. P-CMM is the key tool they adopted for this purpose. 
By the end of the second stage, the company set a new vision for its future, deciding to add construction-related IT projects to its portfolio of projects, penetrate into the market of neighboring countries, and carry out Engineering-Procurement-Construction (EPC) projects. Consequently, the company had to expand its capabilities for delivery and coordination of a wider range of projects in terms of size, expertise requirements, delivery method, and location.

Stage 3: The company's vision for a wider range of project activities required the organization to improve its capacity for delivering projects. To meet this challenge, senior management launched improvement projects to expand the reach of the improvement actions both horizontally and vertically. In addition to the quality management system, projects also sought to improve the organizational project management maturity along with specific project management practices, including time, cost and risk management.

Performing each of these improvement projects required a series of activities for diagnosis and analysis, designing interventions, and leading and managing improvement actions. For instance, the project management office (PMO), which was in charge of the Project Excellence Program for improving organizational project management maturity, developed a 10year strategic plan and conducted a 6-month study to identify the most appropriate model. The organization also compared findings across departments. The PMO conducted diagnoses using OPM3 and Kerzner's Maturity Model and compared the result of the diagnosis with findings of other improvement projects in other units, such as the human resource office. Comparing the diagnosis results helped the two offices to align the identified improvement actions and share their resources. This increased the overall effectiveness of improvement efforts.

Additionally, because project management maturity models are designed purposely for addressing requirements of a project-driven organization, using these tools in a coordinated way 
helped develop a long-term, step-by-step plan for improving relevant parts of the organization's working system, including organization-wide project management processes and employees' capability and increased the comprehensiveness of improvement efforts.

\subsection{Findings of Reviewing Improvement Steps}

Table 4 summarizes the main characteristics and drivers of each stage described in the previous section.

\section{INSERT}

\section{Table 4. Evolution in company's project management practices}

Because XYZ Company is a project-based organization the overall improvement of this firm was dependent on its project management system. However, the case study shows that development and improvement necessitated an organization-wide transformation in work processes, structure, and employees' capability. In summary, review of improvement actions in XYZ Company demonstrates the concepts presented by Truner \& Muller (2003) regarding the impact of projects on firms' structure. Additionally, XYZ Company illustrates Marsh \& Stock (2006) view regarding how the increasing need for project management influences organizational context and leads to a project based organization with a more emphasis on "management by Projects".

More specifically, although improvements in the first and second stage are small incremental changes (i.e., first order change), resulted improvements in project management capability increased the capacity of the organization to develop itself and enabled the 
organization to undertake more sophisticated internal transformation actions over time. In stage 3 XYZ Company implemented more radical, second order change using complex company-wide programs.

\subsection{Tracking Overall Performance of the Organization Over Time}

In order to analyze its current status, the company used different methods including internal and external audits. For example, in the third stage, to assess customer satisfaction, clients completed questionnaires once in a year and follow-up meetings with major clients were held to receive their feedback. Since 2003, the company evaluated its success in achieving the macro-goals set for the current year every year, assessed the effectiveness of its strategies, and prepared a strategic plan for the following year. Review of these annual reports shared with the research team indicated the followings:

- Between 2004 and 2008, on average, the cumulative value of company's contracts increased about $10 \%$ per year: Between these two years, the cumulative value of contacts increased by an average value of 1.8 million Euros per year, reaching to 18 million Euros in 2008 from 9 million Euros in 2004.

- Between 2004 and 2007, the average size and complexity of projects increased about 50\%: In 2004, the company had a total of 5 contracts, with an average value of 1.8 million Euros per contract, while in 2007 the company had 7 projects with an average value of 2.28 million Euros (the total value of contacts in 2007 was 15 million Euros).

- For the first time since 2004, the company achieved its targeted profit margin in 2008: In 2008 , the profit margin achieved by the company was $20 \%$, while the targeted rate was $17 \%$. 
- Between 2003 and 2008, customer satisfactions with design services increased by $12 \%$ : In 2003, only 58\% responses received from clients regarding their satisfactions with design services provided by the company indicated that clients were satisfied with the quality of design services performed by the company, while in 2008 the satisfaction rate was as high as $70 \%$.

\section{Discussion}

Previous work has called from a greater focus on the processes of projectification (Packendorff \& Lindgren 2014). This paper contributes to the debate by examining how a project-based organization institutionalizes project management as a strategic competency. The performance data provided by the company demonstrate overall improvement in customer satisfaction, value of contracts, size and complexity of projects, and financial performance of the company for 6 years. This positive trend is the result of the cumulative effect of all the improvement projects implemented during the first two stages as well as the third stage. The following statements made by one of the senior managers participated in interviews illustrates how creating functional departments (stage one), revising project workflow (stage one), along with providing technical trainings to project managers and project personnel (stage two) helped the company increase customer satisfaction through better execution of projects in stage 3:

"The scope of services for each project is prepared to support our strategic goals and quality policy to create a balance among the benefits of employees, the company and customers. For accurate identification of customers' requirements and expectations, a group of experts is formed in the corresponding functional department to identify the project scope. These groups prepare the scope of engineering services by collecting information related to the project, 
visiting the site, meetings with customers and collecting their points of view. During the execution phase, project managers and project experts work together to supervise construction works and make necessary changes in collaboration with the design team of each project. The Project Manager and the Chief Resident Engineer study all the change requests and send them to the design team to be approved or rejected according to the technical specifications. To organize these tasks we have developed 312 technical work instructions and 30 work procedures systematically. "

Each year since 2005, the Marketing Department of the Company evaluates the effectiveness of this new scoping procedure by comparing the number of scope statements approved by our clients with the total number of statements prepared. One such report shared with the authors indicated that that the approval rate increased from $40.5 \%$ in 2005 to $49.6 \%$ in 2007 as a result of this new scoping approach.

Regarding the role of maturity models, the case study illustrates the strategic role of maturity models in providing a framework for organizational improvement. Maturity models have a self-assessment tool that shows and prioritizes the improvement areas, and they have a body of knowledge that sets forth all the practices required for organizational improvement. For instance, based on the results of the evaluation of questionnaire, the XYZ Company's leaders identified a number of important practices needed to standardize time management processes at the project level, and mapped out the steps they had to take to improve those processes in the organization. The following statements made by the second senior manager interviewed by the research team illustrates how maturity models helped the senior management move from ad hoc analyses of improvement ideas to a systematic approach for identifying improvement areas and aligning different improvement actions: 
"Due to the nature of the construction industry and the rate of change in our country, we believe in responsiveness to changes as a must for the survival of the company. Change management has been a principal part of our strategic management and a senior management team, consisting of members of the Board of Directors and the Managing Director, has been coordinating all the improvement efforts. At the end of each year, the senior management determine improvement areas based on questionnaires received from employees, meetings with clients, and change proposal submitted from project personnel. The senior management team develops strategic change plans in macro change areas, and then process owners identified in the quality management program develop internal plans within each technical department. As far as the project management system is considered, in the Project Excellence Program, our evaluation method for identifying improvement areas has moved from focusing on case-by-case assessments of change proposals submitted by project personnel to using the results of selfassessments based on EFQM Model, OPM3, and Kernzer Model. For example, in 2007, after using OPM3 for assessing project management maturity at the project level, we formed five Excellency Teams with contribution of all of senior managers and organizational departments to take the lead on immediate improvement areas identified based on self-assessment results. These Excellency Teams are working closely with the human resource office on merging best practices from OPM3, Kerzner and P-CMM and developing a comprehensive improvement plan for the project management system and standardizing the organization's body of project management practices."

\subsection{Theoretical Contribution}


Our findings make a number of important theoretical contributions to the body of knowledge in project management. Overall, adoption of a longitudinal process research perspective enabled a temporal view of organizational development. This enabled the identification of the overall trajectory along with the internal transformations of organizational development over time. As far as the scope of improvement projects is considered, reviewing the improvement steps implies that senior management continually diagnosed the firm's performance and performed a series of improvement actions that follows the general trend discovered in the evolution of maturity models (i.e., process control perspective, system perspective, organizational perspective). More specifically, Table 4 shows that the organization's leaders started with the quality management processes in stage 1 and then moved their focus to the business management system in stage 2. Next, in stage 3 they developed an integrated approach for organization-wide improvement and focused on the project management system and the firm's body of the project management knowledge starting at the project level. It is also noteworthy that similar to the first step of improvement in all maturity models, standardization was the first step of improving each of management systems in the XYZ Company

In the first and second stage, management used a set of tools for diagnosing and identifying improvement needs and then adopted a different framework for planning change for later stages. In fact, competence improvement in the first 20 years was in an ad-hoc fashion and a case-by-case basis. Like many organizations in complex environments, management may have followed an improvisational process that ignored longer term paths in favor of short term, sense and respond actions. Project management competency development followed a similar, ad hoc approach. First the role of project management needed to be clarified (Stage 1) before objectives for project management were articulated (Stage 2). A holistic approach only emerged in the third 
stage when maturity models were formally adopted. This development process suggests that project management competence development is contextual as the organization had to first develop the ability to deliver projects in a manner adapted to overall improvement. Only after this ability was developed, was the organization able to adopt a maturity model driven approach to formally categorize and evaluate these capabilities.

Existing maturity models predict the trajectory of project management competency development as a lifecycle approach (Van de Ven \& Poole, 1993), however our case analysis only partially supports that view as the organization exhibited multiple patterns of development over time. This is counter to the maturity models claim that there is a given path of development, i.e., life cycle. Like many other firms, the organization followed an emergent strategy in its early stage of development as it developed knowledge of its external environment and aligned internal capabilities to match. Project management capabilities were therefore developed in a similar ad hoc manner. XYZ's development in the first and second stage is in agreement with the findings of recent work that indicates that firm project management capability development and deployment occur simultaneously (Pellegrinelli, Murray-Webster, \& Turner, 2015). It is only in the third stage that improvement projects have a true life cycle approach, derived from a longterm plan comprised of several improvement projects with distinct start points and ends. This finding provides support for project management competency development as a situated, contextual process which is counter to the claim of maturity models that suggest a single, idealized pattern. In XYZ firm, the idealized pattern only emerged after the firm built sufficient project management capacity to plan and deliver projects within its organizational and external context. 
The second theoretical contribution is that project management competency development has both an evolutionary and a co-evolutionary dynamic. The mode by which knowledge is developed in XYZ Company moved from acquisition to internal generation, moving from evolution (adaption to external demands) to coevolution (both internal and external influencing each other). In early stages, the firm adopted standardized certification process such as ISO 9000. By stage 3, the company invested in a project specific governance structure, a project management office (PMO) that was in charge of the 8-year Project Excellence Program. The PMO expertise was therefore internal to the organization and the PMO was able to transfer project expertise through training courses, building competencies and changing internal attitudes to Project Management. This internal expertise was also able to engage in research as the third stage was designed by the PMO after it conducted research into different maturity models. The PMO then decided to utilize OPM3 as the main model and employ the Kerzner's Model as the supplementary reference. It was also positioned to assist the development of a similar project in the Human Resource office and integrate the outputs of both initiatives.

Finally, in addition to paths and processes of development, the relationship between strategy and project management also changed over time. Crawford et al. (2006) noted that the relationship between project management and strategy can be reactive in some organizations. However, in project based organizations, the opposite can also exist and some organizations might consider project management as a strategic competency and base strategies on their ability to execute projects, programs, and portfolios. Our study partially supports this assertion. For example, Table 4 shows that the company decided to carry out Engineering-ProcurementConstruction (EPC) projects. A review of improvement projects perfumed during the first and second stage shows that the decision for expanding firm's business was made after improving the 
role and competency of project and program managers in the first and second stage. However, note that to support this strategy, the company launched an integrated program for improving the project management system.

\subsection{Practical and Empirical Contribution}

Our study also makes empirical contributions to research and industry. It is noteworthy that XYZ Company is doing business in a developing country in the Middle East where business practices and management philosophies are derived by the large emphasis on the public sector and studies have shown that because of highly centralized political systems and strong national and administrative cultures, administration is highly resistant to international reform trends and adopting western-style administrative solutions (Common, 2008). Project management research in this region is relatively new (Common, 2008), and this study is an initial contribution to a body of knowledge on the process of developing project management capability in these country environments. Many authors have tried to explain differences among industrial firms in different countries on the basis of environmental and cultural factors. For instance, Negandhi (1974) compared management practices and effectiveness of U.S. subsidiaries and comparable firms in Argentina, Brazil, India, the Philippines, Taiwan, and Uruguay and found differences in the extent of attention toward such practices as leadership style, decentralized decision-making, quality management program, and human resources management. Generally, this research has taken a cross sectional approach and does not examine the process or path by which firms have followed to arrive at these different approaches to management practices. Similar studies address differences in project management style in terms of performing practices from project management areas and found significant differences (Zeng, Xie, Sun, \& Tam, 2009). However, 
while this study is admittedly limited in it's generalizability, XYZ's successful use of maturity models indicates that they may be a useful development tool for organizations across country environments.

The second practical and empirical contribution is identification of success factors for overcoming barriers to improving practice in project based organizations over time. As the case indicates, a critical factor in successfully implementing improvement was as a result of increasing the importance of project roles in the organization and developing more capabilities in pursuing strategic objectives. However, a considerable part of the literature related to organizational development is concentrated on recommendations and guidelines for addressing underlying challenges an organization might encounter in planning and managing the required change. In this section, from the observations made during the case study, we list lessons learned from the case study and compare them to the characteristics of successful organizational change management suggested in the literature.

Building capacity for adopting maturity models: While maturity models offer significant promise for improving project practice, in isolation, they may not achieve the required goal of competitive advantage (Jugdev K. \& Thomas J., 2003). Realizing those limitations requires an appropriate level of absorptive capacity to successfully enact change (Wang \& Ahmed, 2007).

- Comparable Lesson Learned from XYZ Company: The findings of this case illustrate how this capacity was built over time. Small first-order improvements in the first and second stage increased the capacity of the organization to undertake a more sophisticated second order change using organizational maturity models in Stage 3. Senior management in XYZ Company also decided to initialize the Project Excellence Program with concentration on four of its six functional departments that were inherently more 
familiar with the concepts of organizational project management and were more ready to take up the new approach. This long-term development path for capacity, though varied, was facilitated by management commitment a factor identified in previous longitudinal project management research on complex projects (Hellström, Ruuska, Wikström, \& Jåfs, 2013)

Choosing the right model: The relevant literature states that in accordance to requirements of each improvement project, different models and standards should be studied and tailored to meet the specific characteristics of the change (Kerzner, 2005).

- Comparable Lesson Learned from XYZ Company: For instance, PMO conducted a separate research project to study different maturity models and decided to utilize OPM3 as the main model and employ the Kerzner's Model as the supplementary reference. As a result of a similar study, the human resource office identified a need to apply basic concepts of P-CMM to enhance the capabilities of human resources.

Coordination between different improvement projects: Despite advantages of maturity models in their comprehensiveness and effectiveness, organizations may need to adopt more than a single model to cover different aspects of their work and address their overall strategic needs. For instance, process maturity models do not cover personnel capabilities and people capability models do not address maturity of processes. Each improvement project has its own unique objectives and resources. However, the scope of these projects frequently overlaps and care must be taken to ensure their coordination (B. Andersen, Henriksen, \& Aarseth, 2007; Cummings \& Worley, 2009)

- Comparable Lesson Learned from XYZ Company: Project Excellence Program from the project management office and the project carried out by the human resource office for 
improving project and program managers' competency were underway concurrently in a specific period of time. In addition to having some individuals on the steering committee of both projects, several meetings were held between the two teams both before and during the implementation phase. Accordingly, to reduce cost and required resources of the projects, these two offices decided to share outcomes of such activities as assessments and training between the two projects instead of conducting them independently.

\section{Limitation of the study}

Although this study makes practical and heretical contribution, its limitations need to be reminded. First, to examine the outcome of improvement actions, one would need to have access to performance data on project level indices and use them to make a comparison before and after and adopting each change. Unfortunately, such data was not available at the time of this study Moreover, in addition to performance outcomes analyzed in this study, organizational improvement projects offers intangible benefits, such as increased organizational learning, enhanced employee job satisfaction, and overall better corporate image. Due to limitations in data available at the time of this study, accounting for the intangible benefits of the improvement actions was not possible. Including intangible benefits will help improve the business case for undertaking improvements projects.

\section{Conclusion}

Organizational improvement requires and is accomplished through changing strategy, structure, and work processes of organizations. Accordingly, practices related to this domain cover a wide range of activities. Maturity models are strategic tools that help understand these 
practices to develop a systematic approach for successful long-term changes. In this study, we looked at application of these models in a project-based construction company to understand the models' ability in providing a comprehensive and effective approach for organizational improvement, along with issues and considerations associated with implementing them. Below is the summary of our findings:

- As showed in the literature review, a wide range of maturity models exist with concentration on improving individual processes (capability maturity models) and groups of processes (organizational process management maturity models) of an organization. Organizations can select a combination of models to fully cover diverse aspects of their work. However, isolated implementation of these models may limit success of improvement activities. In the case study, we found that the XYZ Company had used OPM3 and P-CMM in a strategically coordinated way and this made it possible to align improvement actions and share resources and increased effectiveness of the efforts.

- The relevant literature also shows that development of maturity models originated from quality improvement approaches. In light of this, these models can be used in line with other management and quality improvement paradigms. For example, in the case study after going through a standardization phase using ISO frameworks, the management moved toward implementing maturity models to develop a step-by-step improvement plan.

- In the case study we also found that implementing maturity models and adopting their related concepts played an important role in building a systematic approach for identifying improvement areas and aligning different improvement actions. Likewise, this can increase the effectiveness and comprehensiveness of organizational development 
approaches. However, as with other improvement tools, general organizational change management barriers and challenges arise when implementing maturity models, and organizations' leaders should address such considerations to make the most of these models. 


\section{References}

Andersen, B., Henriksen, B., \& Aarseth, W. (2007). Benchmarking of Project Management Office Establishment: Extracting Best Practices. Journal of Management in Engineering, 23(2), 97-104. doi: doi:10.1061/(ASCE)0742-597X(2007)23:2(97)

Andersen, Erling S., \& Jessen, Svein Arne. (2003). Project maturity in organisations. International Journal of Project Management, 21(6), 457-461. doi: http://dx.doi.org/10.1016/S0263-7863(02)00088-1

Backlund, F., Chronéer, D., \& Sundqvist, E. (2014). Project Management Maturity Models - A Critical Review: A Case Study within Swedish Engineering and Construction Organizations. Procedia - Social and Behavioral Sciences, 119(0), 837-846. doi: http://dx.doi.org/10.1016/j.sbspro.2014.03.094

Bate, Roger. (1995). A systems engineering capability maturity model, version 1.1. Pittsburgh, Pa.: Carnegie Mellon University, Software Engineering Institute.

Bate, Roger, \& Shrum, Sandra. (1998). CMM Integration (CMMI) Framework, NEWS AT SEI. Retrieved January 19, 2013, from http://www.sei.cmu.edu/library/abstracts/news-at-sei/featuresept98pdf.cfm

Baumert, John H., \& McWhinney, Mark S. (1992). Software measures and the capability maturity model. Pittsburgh, Pa.: Carnegie Mellon University, Software Engineering Institute.

Bellini, Emilio, \& Lo Storto, Corrado. (2006). The impact of software capability maturity model on knowledge management and organisational learning: empirical findings and useful insights. International Journal of Information Systems and Change Management, 1(4), 339-373.

Campos, Krystl, \& Trees, Lauren. (2008). Process measures and analytics : the right data for the right decisions : best practices report. Houston, TX: American Productivity and Quality Center.

Chandler, Alfred Dupont. (1969). Strategy and structure : chapters in the history of the industrial enterprise. Cambridge, Mass.: M.I.T. Press.

Cleland, David I., \& Ireland, Lewis R. (2006). Project management : strategic design and implementation. New York: McGraw-Hill.

Common, R. . (2008). Administrative change in the [Persian] Gulf: modernization in Bahrain and Oman Source. International Review of Administrative Sciences, 74 (2), 177-193.

Construction Industry Institute. (2006). CII Best Practices Guide : Improving Project Performance. Austin, Tx: Construction Industry Institute.

Construction Industry Institute. (2009). The Implementation Planning Model : Steps to Success. Austin, Tx: Construction Industry Institute

Cooke-Davies, Terry. (2002). The "real" success factors on projects. International Journal of Project Management, 20(3), 185-190. doi: http://dx.doi.org/10.1016/S0263-7863(01)00067-9

Cooke - Davies, Terence J, Crawford, Lynn H, \& Lechler, Thomas G. (2009). Project management systems: Moving project management from an operational to a strategic discipline. Project Management Journal, 40(1), 110-123.

Crawford, L., Hobbs, J Brian , \& Turner, John Rodney (2006). Aligning Capability with Strategy: Cagegorizing projects to do the right projects and to do them right. Project management journal., 37(2), 38-50.

Crosby, Philip B. (1979). Quality is free : the art of making quality certain. New York: McGraw-Hill.

Cummings, Thomas G., \& Worley, Christopher G. (2009). Organization Development and Change (9th ed.). Mason, Ohio: South-Western Cengage Learning.

Curtis, Bill, Hefley, Bill, Miller, Sally, \& Carnegie-Mellon Univ Pittsburgh Pa Software Engineering, Inst. (2009). People Capability Maturity Model (P-CMM) Version 2.0, Second Edition. from http://handle.dtic.mil/100.2/ADA512354

Dai, Christine Xiaoyi, \& Wells, William G. (2004). An exploration of project management office features and their relationship to project performance. International Journal of Project Management, 22(7), 523-532. doi: http://dx.doi.org/10.1016/j.ijproman.2004.04.001

Erdogan, B., Anumba, C., Bouchlaghem, D., \& Nielsen, Y. Collaboration Environments for Construction: Management of Organizational Changes. Journal of Management in Engineering, O(ja), null. doi: doi:10.1061/(ASCE)ME.1943-5479.0000231

Ford, R. C., \& Randolph, W.A. (1992). Cross-Functional Structures: A Review and Integration of Matrix Organization and Project Management. Journal of Management Journal of Management, 18(2), 267-294.

Gareis, R. (1989). 'Management by projects': the management approach for the future. International journal of project management, 7(4), 243-249. 
Gareis, R. (1991). Management by projects: the management strategy of the 'new' project-oriented company. International journal of project management, 9(2), 71-76.

Graham, Richard. (1999). Managing the project management process in Aerospace and Construction: a comparative approach. International Journal of Project Management, 17(1), 39-45. doi: http://dx.doi.org/10.1016/S0263-7863(97)00072-0

Green, S. . (2005). Strategic Project Management: From Maturity Model to Project Leadership. Project Management Journal, 36(2), 60-73.

Hakes, Chris. (2007). The EFQM excellence model for Assessing Organizational Performance For Assessing Organizational Performance - A Management Guide. from http://public.eblib.com/EBLPublic/PublicView.do?ptiID=998718

Hellström, Magnus, Ruuska, Inkeri, Wikström, Kim, \& Jåfs, Daniel. (2013). Project governance and path creation in the early stages of Finnish nuclear power projects. International Journal of Project Management, 31(5), 712-723. doi: http://dx.doi.org/10.1016/j.ijproman.2013.01.005

Ibrahim, Linda, Bradford, Bill, Cole, David, LaBruyere, Larry, Leinneweber, Heidi, Piszczek, Dave, ... Wells, Curt. (2001). The Federal Aviation Administration Integrated Capability Maturity Model (FAA-iCMM®), Version 2.0. Washington, DC: Federal Aviation Administration.

International Project Management Association. (2002). IPMA Project Excellence Model. Retrieved December 05, 2009, from http://www.ipma.ch/awards/projexcellence/Pages/ProjectExcellenceModel.aspx

Jugdev K., \& Thomas J. (2003). Project Management Maturity Models: the Silver Bullets of Competitive Advantages. Project Management Journal, 33(4), 4-14.

Jugdev, Kam, \& Müller, Ralf. (2005). A retrospective look at our evolving understanding of project success. Project management journal, 36(4), 19-31.

Kerzner, Harold. (2001). Strategic planning for project management using a project management maturity model.

Kerzner, Harold. (2005). Project management : a systems approach to planning, scheduling, and controlling. New York, N.Y.; [Great Britain]: Wiley.

Klein, Louis, Biesenthal, Christopher, \& Dehlin, Erlend. (2015). Improvisation in project management: A praxeology. International Journal of Project Management, 33(2), 267-277. doi: http://dx.doi.org/10.1016/j.ijproman.2014.01.011

Koskinen, Kaj U. (2012). Organizational Learning in Project-Based Companies: A Process Thinking Approach. Project Management Journal, 43(3), 40-49. doi: 10.1002/pmj.21266

Kwak, Y. H. , \& Ibbs, C. W. (1997). The Berkeley Project Management Process Maturity Model, Measuring the Value of Project Management. . Retrieved December 05, 2009, from http://home.gwu.edu/ kwak/Berkeley_Model.pdf

Kwak, Y. H., \& Ibbs, C. W. . (2002). Project Management Process Maturity Model. Journal of Management in Engineering, 18(3), 150-155.

Langley, A. (1999). Strategies for Theorizing From Process Data. Academy of Management Review Academy of Management Review, 24(4), 691-710.

Lappe, Marc, \& Spang, Konrad. (2014). Investments in project management are profitable: A case study-based analysis of the relationship between the costs and benefits of project management. International Journal of Project Management, 32(4), 603-612. doi: http://dx.doi.org/10.1016/j.ijproman.2013.10.005

Ling, Florence Yean Yng, Ong, Shi Ying, Ke, Yongjian, Wang, Shouqing, \& Zou, Patrick. (2014). Drivers and barriers to adopting relational contracting practices in public projects: Comparative study of Beijing and Sydney. International Journal of Project Management, 32(2), 275-285. doi: http://dx.doi.org/10.1016/j.ijproman.2013.04.008

Maier, Anja M, Moultrie, James, \& Clarkson, PJohn. (2012). Assessing organizational capabilities: reviewing and guiding the development of maturity grids. Engineering Management, IEEE Transactions on, 59(1), 138159.

Marsh, Sarah J., \& Stock, Gregory N. (2006). Creating Dynamic Capability: The Role of Intertemporal Integration, Knowledge Retention, and Interpretation. Journal of Product Innovation Management, 23(5), 422-436.

Martinsuo, Miia, Hensman, Nicole, Artto, Karlos, Kujala, Jaakko, \& Jaafari, Ali. (2006). Project-Based Management as an Organizational Innovation: Drivers, Changes, And Benefits Of Adopting Project-Based Management. Project Management Journal, 37(3), 87-97.

Massini, Silvia, \& Pettigrew, Andrew M. (2003). Complementarities in organizational innovation and performance. Innovative Forms of Organizing, AM Pettigrew, R. Whittington, L. Melin, C. Sanchez-Runde, FVD Bosch, W. Ruigrok and T. Numagami (eds.), 133-172. 
Medina, Rolf, \& Medina, Alicia. (2014). The project manager and the organisation's long-term competence goal. International Journal of Project Management, 32(8), 1459-1470. doi: http://dx.doi.org/10.1016/j.ijproman.2014.02.011

Miller, Danny. (1982). Evolution and Revolution: A Quantum View of Structural Change in Organizations. $J$ Management Studies Journal of Management Studies, 19(2), 131-151.

Mullaly, Mark. (2006). Longitudinal Analysis of Project Management Maturity. Project Management Journal, 37(3), 62-73.

Mullaly, Mark, \& Thomas, Janice L. (2009). Exploring the dynamics of value and fit: Insights from project management. Project Management Journal, 40(1), 124-135. doi: 10.1002/pmj.20104

Negandhi, Anant R. (1974). A cross-cultural comparative study of management. Omega Omega, 2(6), 785-791.

Nolan, Richard L. (1973). Managing the computer resource: a stage hypothesis. Communications of the ACM, 16(7), 399-405.

Packendorff, J. (1995). Inquiring into the Temporary Organization: New Directions for Project Management Research. Scandinavian Journal of Management, 11(4), 319-333.

Packendorff, J., \& Lindgren, M. (2014). Projectification and its consequences: Narrow and broad conceptualisations. South African Journal of Economic and Management Sciences, 17(1), 7-21.

Paulk, Mark C., \& Software Engineering Institute. (1993). Capability maturity model for software, version 1.1. Pittsburgh, Pa.: Carnegie Mellon University, Software Engineering Institute (SEI).

Pellegrinelli, Sergio, Murray-Webster, Ruth, \& Turner, Neil. (2015). Facilitating organizational ambidexterity through the complementary use of projects and programs. International Journal of Project Management, 33(1), 153-164. doi: http://dx.doi.org/10.1016/j.ijproman.2014.04.008

Project Management Institute. (2003). Organizational project management maturity model (OPM3) : knowledge foundation. Newton Square, Pa: Project Management Institute.

Scott, W. Richard. (1995). Institutions and organizations. Thousand Oaks: SAGE.

Seppänen, Veikko. (2002). Evolution of competence in software subcontracting projects. International Journal of Project Management, 20(2), 155-164. doi: http://dx.doi.org/10.1016/S0263-7863(00)00043-0

Shah, Rachna, \& Ward, Peter T. (2007). Defining and developing measures of lean production. Journal of operations management, 25(4), 785-805.

Shenhar, Aaron J. (2001). One size does not fit all projects: exploring classical contingency domains. Management Science, 47(3), 394-414.

Software Engineering Institute. (2007). Introduction to the architecture of the CMMI framework. Pittsburgh, Pa.: Carnegie Mellon University, Software Engineering Institute (SEI).

Turner, J. Rodney, \& Muller, Ralf. (2002). On The Nature of the Project as a Temporary Organization: Henley Management College.

Van de Ven, Andrew H., \& Poole, Marshall Scott. (1993). Explaining development and change in organizations. [Minneapolis, Minn.]: Strategic Management Research Center, University of Minnesota.

Voss, Chris, Tsikriktsis, Nikos, \& Frohlich, Mark. (2002). Case research in operations management. International Journal of Operations \& Production Management, 22(2), 195-219.

Wang, Catherine, \& Ahmed, Pervaiz K. (2007). Dynamic capabilities: A review and research agenda. The International Journal of Management Reviews, 9(1), 31-51.

Wendler, Roy. (2012). The maturity of maturity model research: A systematic mapping study. Information and Software Technology, 54(12), 1317-1339. doi: http://dx.doi.org/10.1016/j.infsof.2012.07.007

Yazici, Hulya Julie. (2009). The role of project management maturity and organizational culture in perceived performance. Newtown Square, Pa.: Project Management Institute.

Young, Raymond, \& Grant, Jamie. (2015). Is strategy implemented by projects? Disturbing evidence in the State of NSW. International Journal of Project Management, 33(1), 15-28. doi: http://dx.doi.org/10.1016/j.ijproman.2014.03.010

Zeng, S. X., Xie, X. M., Sun, P. M., \& Tam, C. M. (2009). Identifying cultural difference in R\&D project for performance improvement: A field study. J. Bus. Econ. Manage. Journal of Business Economics and Management, 10(1), 61-70.

Zqikael, O., Levin, G., \& Rad, P. F. (2008). Top Management Support - The Project Friendly Organization. Cost Enginnering, 50(9), 22-29. 
TABLE 1. Main Steps in the Evolution of Maturity Models

\begin{tabular}{|c|c|c|}
\hline Evolution Step & Time Period & Outstanding Approaches \\
\hline $\begin{array}{l}\text { Preliminary efforts for developing a structured } \\
\text { method for quality management and } \\
\text { improvement in organizations }\end{array}$ & 1930-1980 & Statistical Quality Control, TQM \\
\hline $\begin{array}{c}\text { Maturity concept evolved in software } \\
\text { engineering field }\end{array}$ & Early 1980s & Maturity framework \\
\hline $\begin{array}{l}\text { Holistic approaches developed for identifying } \\
\text { software improvement areas }\end{array}$ & $1985-1995$ & SEI's capability maturity models \\
\hline $\begin{array}{l}\text { Maturity and excellence concepts adopted } \\
\text { beyond software engineering field into project } \\
\text { and business management processes }\end{array}$ & 1990-1996 & $\begin{array}{l}\text { EFQM excellence model, IPMA's } \\
\text { project excellence model, The } \\
\text { Berkeley project management } \\
\text { process maturity model }\end{array}$ \\
\hline $\begin{array}{l}\text { Integrated approaches developed for software } \\
\text { development processes }\end{array}$ & 1996-1999 & Integrated capability maturity model \\
\hline $\begin{array}{l}\text { Excellence and maturity models adopted in } \\
\text { project management field } \\
\text { Comprehensive models developed for } \\
\text { organizational-wide improvements in project- } \\
\text { driven organizations }\end{array}$ & 2000-Present & $\begin{array}{l}\text { IPMA competency baseline, Project } \\
\text { management competency } \\
\text { development framework, PM } \\
\text { Solutions' project portfolio } \\
\text { management maturity model, OPM3 }\end{array}$ \\
\hline
\end{tabular}


TABLE 2. Common Features Among Maturity Models

\begin{tabular}{c|c}
\hline Common Features & Relevant Element \\
\hline Describing the concept of maturity & Body of knowledge \\
\hline Defining maturity levels and the maturity path & Body of knowledge \\
\hline Providing a self-assessment tool & Appraisal \\
\hline Presenting practices required for improving maturity & Body of knowledge \\
\hline Evaluating effectiveness of improvement actions & Improvement, Appraisal \\
\hline Dependency on a specific standard & Body of knowledge \\
\hline Continuous improvement as the last level of maturity & Improvement \\
\hline Applying incremental changes & Improvement, Body of knowledge \\
\hline
\end{tabular}


TABLE 3. Major Improvement Actions and Outcomes of XYZ Company

\begin{tabular}{|c|c|c|}
\hline Period & Change Actions & Main Outcomes \\
\hline $\begin{array}{c}1982- \\
1993\end{array}$ & $\begin{array}{c}\text { Functional matrix organization structure } \\
\text { Separate departments for providing design and } \\
\text { supervision services }\end{array}$ & $\begin{array}{l}\text { Project managers under the functional } \\
\text { department managers, limited improvement } \\
\text { opportunity for project managers } \\
\text { Time-consuming constructability analysis }\end{array}$ \\
\hline 1993 & $\begin{array}{l}\text { Supervision department merged within technical } \\
\text { engineering departments }\end{array}$ & $\begin{array}{c}\text { Interaction between design and supervision } \\
\text { teams improved, constructability analysis } \\
\text { facilitated }\end{array}$ \\
\hline 1997 & $\begin{array}{l}\text { Separate division established in each department } \\
\text { for providing project management services to } \\
\text { projects } \\
\text { Standardization program based on ISO standards } \\
\text { Implemented }\end{array}$ & $\begin{array}{l}\text { Authority for project managers increased (still } \\
\text { under functional managers) } \\
\text { Career development opportunity for project } \\
\text { managers increased }\end{array}$ \\
\hline 1998 & $\begin{array}{c}\text { Technical training program implemented for } \\
\text { heads of the technical departments (program } \\
\text { managers) }\end{array}$ & $\begin{array}{c}\text { Technical competences of program managers } \\
\text { improved } \\
\text { ISO 9000-1994 certification obtained }\end{array}$ \\
\hline $\begin{array}{l}2000- \\
2001\end{array}$ & $\begin{array}{c}\text { Training program focusing on managerial skills } \\
\text { implemented for program managers } \\
\text { Program launched for implementing TQM } \\
\text { concepts }\end{array}$ & $\begin{array}{l}\text { Managerial competences of program managers } \\
\text { improved (better communication with clients) } \\
\text { "Commitment To Excellence" awarded to the } \\
\text { firm (the national version of the EFQM award) }\end{array}$ \\
\hline 2002 & $\begin{array}{c}\text { Implementing the P-CMM outsourced } \\
\text { Comprehensive project management workshop } \\
\text { Implemented for program and project } \\
\text { managers by a PMI's certified instructor }\end{array}$ & $\begin{array}{l}\text { Human recourse management practices } \\
\text { improved } \\
\text { The project management competences of the } \\
\text { program and project managers improved }\end{array}$ \\
\hline 2004 & $\begin{array}{l}\text { Comprehensive project management training } \\
\text { program for program and project managers } \\
\text { implemented by internal instructors }\end{array}$ & $\begin{array}{l}\text { Project management competences of the } \\
\text { program and project managers improved }\end{array}$ \\
\hline 2005 & $\begin{array}{l}\text { Comprehensive project management training } \\
\text { program implemented for project engineers } \\
\text { Plan for establishing an organizational } \\
\text { management system developed } \\
\text { Focus on project management processes for } \\
\text { improvement (work flow at the project level) }\end{array}$ & $\begin{array}{c}\text { Project management related knowledge of the } \\
\text { project managers improved } \\
\text { Human resource office and the project } \\
\text { management office established } \\
\text { Role of projects in the organization's business } \\
\text { enhanced }\end{array}$ \\
\hline 2006 & $\begin{array}{c}\text { Work on the Project Excellence Program in PMO } \\
\text { Project management maturity at the project level } \\
\text { assessed using OPM3 }\end{array}$ & $\begin{array}{c}\text { PMO took charge of the project process } \\
\text { improvement and researched maturity models } \\
\text { Need for standardization of project management } \\
\text { processes identified }\end{array}$ \\
\hline $\begin{array}{l}\text { 2007- } \\
\text { Present }\end{array}$ & $\begin{array}{c}\text { PMO made a detailed planning for the Project } \\
\text { Excellence Program } \\
\text { Standardization of project management processes } \\
\text { started as a part of the Project Excellence } \\
\text { Program }\end{array}$ & $\begin{array}{c}\text { Working on merging OPM3, Kerzner and P- } \\
\text { CMM in order to develop a comprehensive } \\
\text { improvement approach } \\
\text { Project management practices standardized and } \\
\text { developing the company's body of project } \\
\text { management knowledge started }\end{array}$ \\
\hline
\end{tabular}




\section{Table 4. Evolution in company's project management practices}

\begin{tabular}{c|c|c|c}
\hline Stage & Time Frame & Area of Improvements & Main Improvement Objectives \\
\hline First stage & $\begin{array}{c}1982-1997 \\
(15 \text { years })\end{array}$ & $\begin{array}{c}\text { Work flow in the project and } \\
\text { organizational level } \\
\text { Organizational structure (organizational } \\
\text { chart, roles and responsibilities, } \\
\text { required qualifications) }\end{array}$ & $\begin{array}{r}\text { Improving the role of project and } \\
\text { program managers and moving } \\
\text { toward employing the project } \\
\text { driven business approach* }\end{array}$ \\
\hline Second stage & $\begin{array}{c}1998-2002 \\
(5 \text { years })\end{array}$ & $\begin{array}{c}\text { Project management teams } \\
\text { Systemizing the quality management } \\
\text { processes }\end{array}$ & $\begin{array}{c}\text { Improving competencies of the } \\
\text { project and program managers** } \\
\text { Improving the overall performance }\end{array}$ \\
\hline Third stage & $\begin{array}{c}\text { 2003-present } \\
\text { adoption of companywide project } \\
\text { management maturity framework }\end{array}$ & $\begin{array}{c}\text { Standardizing the project } \\
\text { management body of } \\
\text { practices*** }\end{array}$ \\
\hline
\end{tabular}

*Supporting quote from interviews with senior managers:

"During the first years after the company was established, we had a centralized planning and control approach for all projects, which was not well supported by project managers as they had to work under the supervision of department heads and did not have full authority for making critical decisions. Managerial and technical decisions had to go through a long process of approval from project personnel in each division up to non-project personnel at the department level who had decision-making authorities, which was not the most effective and fastest way to resolve project-level issues."

** Supporting quote from interviews with senior managers:

The majority of our project managers have an engineering degree and after giving them more power and more authority to make project management decisions, we noticed the need for providing project-management related trainings.

*** Supporting quote from interviews with senior managers:

We have been using ISO quality standards for standardizing main and supporting management processes since early days after the establishment of the project. In recent years, as senior management and employees gained more knowledge and expertise in project management, and with the advent of various project management maturity models, we also paid specific attention to standardizing our project management system.... For example, in 2007, after using OPM3 for assessing project management maturity at the project level, we formed five Excellency Teams with contribution of all of senior managers and organizational departments to take the lead on immediate improvement areas identified based on self-assessment results. These Excellency Teams are working closely with the human resource office on merging best practices from OPM3, Kerzner and P-CMM and developing a comprehensive improvement plan for the project management system and standardizing the organization's body of project management practices." 